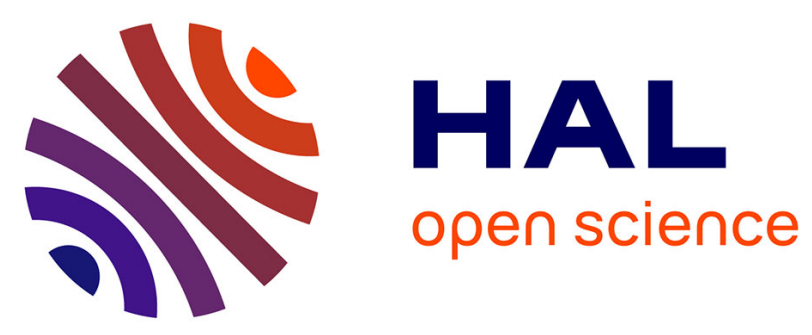

\title{
Improved synthesis, resolution, absolute configuration determination and biological evaluation of HLM006474 enantiomers
}

Miyanou Rosales-Hurtado, Alexandre Lebeau, Cyril Bourouh, Gerardo Cebrian Cebrian-Torrejon, Muriel Albalat, Marion Jean, Jean-Valère

Naubron, Jean Sebastien Annicotte, Zohra Benfodda, Patrick Meffre

\section{To cite this version:}

Miyanou Rosales-Hurtado, Alexandre Lebeau, Cyril Bourouh, Gerardo Cebrian Cebrian-Torrejon, Muriel Albalat, et al.. Improved synthesis, resolution, absolute configuration determination and biological evaluation of HLM006474 enantiomers. Bioorganic and Medicinal Chemistry Letters, 2019, 29, pp.380-382. 10.1016/j.bmcl.2018.12.037 . hal-01968387

\section{HAL Id: hal-01968387 \\ https://hal.science/hal-01968387}

Submitted on 7 Jan 2019

HAL is a multi-disciplinary open access archive for the deposit and dissemination of scientific research documents, whether they are published or not. The documents may come from teaching and research institutions in France or abroad, or from public or private research centers.
L'archive ouverte pluridisciplinaire HAL, est destinée au dépôt et à la diffusion de documents scientifiques de niveau recherche, publiés ou non, émanant des établissements d'enseignement et de recherche français ou étrangers, des laboratoires publics ou privés.

\section{(ㅇ)(1) $\$$}

Distributed under a Creative Commons Attribution - NonCommercial - NoDerivatives 44.0 


\title{
Improved synthesis, resolution, absolute configuration determination and biological evaluation of HLM006474 enantiomers
}

\author{
Miyanou Rosales-Hurtado ${ }^{\mathrm{a}}$, Alexandre Lebeau ${ }^{\mathrm{a}}$, Cyril Bourouh ${ }^{\mathrm{d}}$, Gerardo Cebrian-Torrejon ${ }^{\mathrm{a}}$, \\ Muriel Albalat ${ }^{\mathrm{b}}$, Marion Jean ${ }^{\mathrm{b}}$, Jean-Valère Naubron ${ }^{\mathrm{c}}$, Jean-Sébastien Annicotte ${ }^{\mathrm{d}}$, \\ Zohra Benfodda ${ }^{\text {a, }}$, Patrick Meffre ${ }^{a, *, 1}$ \\ a UNIV. NIMES, EA7352 CHROME, Rue du Dr G. Salan, 30021 Nîmes Cedex 1, France \\ ${ }^{\mathrm{b}}$ Aix Marseille Univ, CNRS, Centrale Marseille, iSm2, Marseille, France \\ 'Aix Marseille Univ, CNRS, Centrale Marseille, FSCM, Spectropole, Marseille, France \\ ${ }^{d}$ CNRS UMR 8199, European Genomic Institute for Diabetes (EGID), Institut Pasteur de Lille, University of Lille, Lille F-59000, France
}

\section{A R T I C L E I N F O}

\section{Keywords:}

HLM006474 enantiomers

Betti reaction

Solvent-free reaction

Microwave assisted synthesis

Absolute configuration determination

Biological activity

\begin{abstract}
A B S T R A C T
An improved green synthesis of the E2F inhibitor HLM0066474 is described, using solvent-free and microwave irradiation conditions. The two enantiomers are separated using semi-preparative separation on Chiralpak ID and their absolute configuration is determined by vibrational circular dichroism (VCD) analysis. Biological evaluation of both enantiomers on E2F1 transcriptional activity reveals that the $(+)-R$, but not the $(-)-S$ enantiomer is biologically active in repressing E2F1 transcriptional activity.
\end{abstract}

HLM006474 1 is a small molecule pan-inhibitor of E2F-DNA binding (Fig. 1) and is a potent inhibitor of melanocytes proliferation. ${ }^{1}$ Moreover, HLM006474 1 synergizes with paclitaxel which suggests that this small molecule may have efficacy in lung cancer. ${ }^{2}$

Although it is a commercially available compound, HLM006474 1 is rather expensive. The synthesis of this compound has been described in 2008 using a two-step sequence. First step is a Williamson reaction starting from 4-hydroxy-3-methyl benzaldehyde 2 and bromoethane in dimethylformamide. Second step is a three-component Betti reaction between the obtained 4-ethoxy-3-methyl benzaldehyde 3, 2-aminopyridine 4 and 2-methyl-3-quinolinol 5 in ethanol (Fig. 2). ${ }^{1}$ This procedure suffers from low yield and long reaction time.

Moreover, HLM006474 1 presents one carbon stereocenter and to the best of our knowledge, it has only been tested on biological systems in racemic form although a difference in biological activity would be expected between the two enantiomers due to the inherent chirality of biological systems. We decided to improve the synthetic access to this compound, perform the resolution and the determination of the absolute configuration of the two enantiomers and evaluate their biological activities as inhibitors of E2F1 transcriptional activity.

The first step of the synthesis is performed using the same conditions as the literature. ${ }^{1}$ In our hands, product 3 is obtained in $77 \%$ yield on $64 \mathrm{mmol}$ scale after work up (litt. ${ }^{1}: 65 \%$ on $6.6 \mathrm{mmol} \mathrm{scale}$ ) and is used without further purification in the next step (Fig. 3). The second step is a Betti reaction ${ }^{3,4}$. Betti reaction is a Mannich-type aminoalkylation multicomponent reaction between ammonia or amines, formaldehyde or aldehydes and enolisable carbonyl compounds or phenol/naphtols. It was originally performed in ethanol as solvent ${ }^{5}$ but these conditions for compound 1 result in low yield and long reaction time. ${ }^{1}$ In order to optimize the synthesis of this compound we tried different and/or greener reaction conditions also used for Betti reaction:water, ${ }^{6,7}$ acetonitrile, ${ }^{7}$ PEG $-400^{8}$ as solvent or solvent-free conditions ${ }^{9}$ as well as microwave irradiation $(\mathrm{MW})^{10-12}$ at different temperatures (Fig. 3).

The results are reported in Table 1 (thermal conditions) and Table 2 (microwave irradiation).

Experimental conditions close to the literature ${ }^{1}$ led to analogous results (Table 1, entry 1 ). Using acetonitrile at $\mathrm{rt}$ or $85^{\circ} \mathrm{C}$, or PEG-400 as solvent were unsuccessful (Table 1, entries 4-6). Water as solvent at $\mathrm{rt}$ increased notably the yield to $29 \%$ although a decreased yield was observed with water at reflux (Table 1, entries 2 and 3). Best results $(66 \%)$ were obtained in solvent-free conditions at $55{ }^{\circ} \mathrm{C}$ in only one day reaction time (Table 1 , entry 7 ) but we noticed that a slight excess of amine 4 at $95^{\circ} \mathrm{C}$ could have an interesting effect on reaction time

\footnotetext{
- Corresponding author.

E-mail address: patrick.meffre@unimes.fr (P. Meffre).

${ }^{1}$ These authors contributed equally.
} 


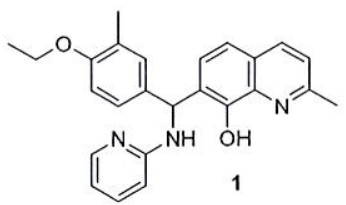

Fig. 1. Structure of HLM006474 1

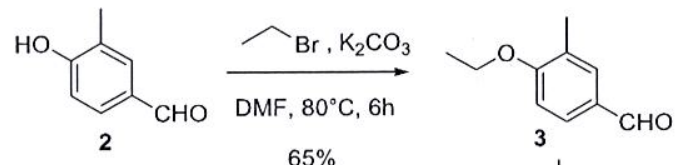

$65 \%$

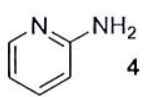

$\mathrm{EtOH}, \mathrm{rt}, 14$ days

$12 \%$<smiles>CCOc1ccc(C(Nc2ccccn2)c2ccc3ccc(C)nc3c2O)cc1C</smiles>

Fig. 2. Synthesis of HLM006474 according to Ma et al. ${ }^{1}$.

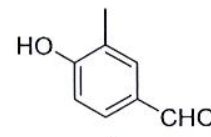

$\begin{gathered}\text { 1- } \mathrm{DMF}, \mathrm{K}_{2} \mathrm{CO}_{3} \\ \mathrm{rt}, 25 \mathrm{~min} .\end{gathered}$
$\underset{\text { 2- } \mathrm{CH}_{3} \mathrm{CH}_{2} \mathrm{Br},}{80^{\circ} \mathrm{C}, 3 \mathrm{~h}}$

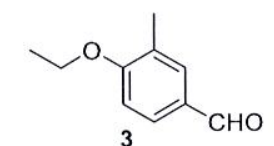
$80^{\circ} \mathrm{C}, 3 \mathrm{~h}$

$77 \%$<smiles>Cc1ccc2cccc(O)c2n1</smiles><smiles>Nc1ccccn1</smiles>

conditions : see Tables 1 and 2

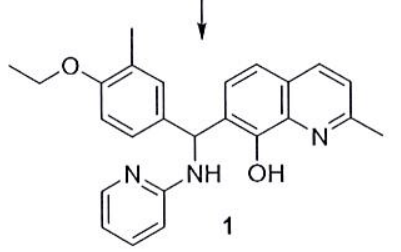

Fig. 3. Improved synthesis of HLM006474.

Table 1

Synthesis of 1 using Betti reaction in different thermal reaction conditions (Fig. 3).

\begin{tabular}{lllll}
\hline Entry & Temperature & Solvent & Reaction time & Yield $^{\mathrm{a}}$ in 1 \\
\hline $1^{\mathrm{b}}$ & $\mathrm{rt}$ & $\mathrm{EtOH}$ & $10 \mathrm{~d}$ & $15 \%$ \\
2 & $\mathrm{rt}$ & $\mathrm{H}_{2} \mathrm{O}$ & $8 \mathrm{~d}$ & $29 \%$ \\
3 & $100^{\circ} \mathrm{C}$ & $\mathrm{H}_{2} \mathrm{O}$ & $2 \mathrm{~d}$ & $9 \%$ \\
4 & $\mathrm{rt}$ & $\mathrm{CH}_{3} \mathrm{CN}$ & $9 \mathrm{~d}$ & $3 \%$ \\
5 & $85^{\circ} \mathrm{C}$ & $\mathrm{CH}_{3} \mathrm{CN}$ & $3 \mathrm{~d}$ & $5 \%$ \\
6 & $\mathrm{rt}$ & $\mathrm{PEG}-400$ & $36 \mathrm{~d}$ & $5 \%$ \\
7 & $55^{\circ} \mathrm{C}$ & - & $1 \mathrm{~d}$ & $66 \%$ \\
$8^{\mathrm{c}}$ & $95{ }^{\circ} \mathrm{C}$ & - & $6,5 \mathrm{~h}$ & $45 \%$ \\
\hline
\end{tabular}

a Yield after purification on $6 \mathrm{mmol}$ scale unless otherwise noted.

b Experimental conditions close to Ma et al. ${ }^{1}$

${ }^{c}$ Reaction performed on $1 \mathrm{mmol}$ scale, 1.2 eq. of amine 4 is used.
Table 2

Synthesis of 1 using Betti reaction and MW irradiation ${ }^{\mathrm{a}}$ (Fig. 3).

\begin{tabular}{lllll}
\hline Entry & Temperature & Solvent & Reaction time & Yield in 1 \\
\hline 1 & $60^{\circ} \mathrm{C}$ & - & $12 \mathrm{~h}$ & $33 \%$ \\
2 & $95^{\circ} \mathrm{C}$ & - & $6.5 \mathrm{~h}$ & $57 \% \%^{\mathrm{c}}$ \\
3 & $95^{\circ} \mathrm{C}$ & - & $6.5 \mathrm{~h}$ & $55 \%^{\mathrm{d}}$ \\
$4^{\mathrm{e}}$ & $95{ }^{\circ} \mathrm{C}$ & - & $6.5 \mathrm{~h}$ & $70 \%^{\mathrm{c}}$ \\
$5^{\mathrm{e}}$ & $95{ }^{\circ} \mathrm{C}$ & - & $6.5 \mathrm{~h}$ & $67 \%^{\mathrm{d}}$ \\
$6^{\mathrm{e}}$ & $110^{\circ} \mathrm{C}$ & - & $3 \mathrm{~h}$ & $58 \%^{\mathrm{c}}$ \\
$7^{\mathrm{e}}$ & $110^{\circ} \mathrm{C}$ & - & $3 \mathrm{~h}$ & $58 \% \%^{\mathrm{d}}$ \\
8 & $60^{\circ} \mathrm{C}$ & - & $24 \mathrm{~h}$ & $71 \%^{\mathrm{c}}$ \\
9 & $60^{\circ} \mathrm{C}$ & - & $24 \mathrm{~h}$ & $71 \%^{\mathrm{d}}$ \\
\hline
\end{tabular}

a $\mathrm{MW}: 300 \mathrm{~W}$

b Yield after purification on $1 \mathrm{mmol}$ scale unless otherwise noted.

${ }^{c}$ Reactions were run in triplicate - the mean yield is given.

d Reaction was performed on $6 \mathrm{mmol}$ scale.

1.2 eq. of amine 4 is used.

(decreased to 6,5h) and yield (45\%) (Table 1, entry 8). Reaction conditions using microwaves are known to possibly facilitate this reaction. Therefore we decided to study microwave (MW) reaction conditions (Table 2).

Using microwave reaction conditions, a $55-57 \%$ yield is obtained in only $6,5 \mathrm{~h}$ at $95^{\circ} \mathrm{C}$ (entries 2 and 3 compared to entry 1) and the yield is increased to $67-70 \%$ using 1.2 eq. excess of amine 4 (entries 4 and 5). At $110{ }^{\circ} \mathrm{C}$ and in $3 \mathrm{~h}$ reaction time, however, yields decreased to $58 \%$ (entries 6 and 7). Good results $\left(71 \%\right.$ ) are also obtained at $60^{\circ} \mathrm{C}$ in $24 \mathrm{~h}$ (entries 8 and 9). The reactions were at first performed on $1 \mathrm{mmol}$ scale in triplicate (entries $2,4,6,8$ ) to ascertain reproducibility and yields were confirmed on $6 \mathrm{mmol}$ scale (entries $3,5,7,9$ ).

Enantiomers of HLM006474 were separated by HPLC over chiral stationary phase. Chiralpak ID, amylose tris(3-chloro-phenylcarbamate) allowed an excellent baseline separation with a heptane/2-PrOH/TEA $(50 / 50 / 0.1)$ mixture as mobile phase at analytical scale. Enantiomeric excesses can be easily determined by this developed method, which exhibits an enantioselectivity of 1.7 and a resolution of 3.5. The method was extrapolated at preparative on the same chiral column to obtain $190 \mathrm{mg}$ of each enantiomer with an enantiomeric ratio higher than 99.5/0.5 (See Supplementary data).

Infrared (IR) and vibrational circular dichroism (VCD) spectra were recorded for both enantiomers. Calculations were performed on the $(R)$ enantiomer of HLM006474 (see Supplementary data for details): the conformational studies using $\operatorname{SMD}\left(\mathrm{CD}_{2} \mathrm{Cl}_{2}\right)$ /CAM-B3LYP/DGTZVP level have shown that 10 conformations $A_{1}-A_{10}$ must be used to build the average calculated spectra in IR/VCD. A satisfying agreement between the measured and the average calculated spectra has allowed establishing the absolute configuration $(R)$ of the first eluted enantiomer of HLM006474. The assignment of the absolute configuration was confirmed by comparison of experimental and calculated electronic circular dichroism spectra (see Supplementary data)

E2F1 is a transcription factor that regulates gene expression through DNA binding. HLM006474 is a molecule that blocks E2F transcriptional activity by disrupting E2F-DNA binding. ${ }^{1}$ To evaluate whether the HLM006474 enantiomers have different E2F inhibitory activities, we probed E2F1 transcriptional activity after treatment of a human cell line with these molecules. The human embryonic kidney cell line HEK293 was treated for $48 \mathrm{~h}$ with DMSO (as a control), $10 \mu \mathrm{M}(R+S)$ HLM006474, $10 \mu \mathrm{M}(R)$-HLM006474 or $10 \mu \mathrm{M}(S)$-HLM006474 (Fig. 4). Luciferase-based reporter studies using a plasmid construct containing canonical E2F DNA-responsive element fused to the luciferase gene confirmed that the E2F1/DP-1 complex potentiates the promoter activity of this heterologous construct upon DMSO treatment. This effect was blunted upon $10 \mu \mathrm{M}(R+S)$-HLM006474 and $10 \mu \mathrm{M}(R)$ HLM006474, suggesting that these molecules inhibit E2F1/DP-1 transcriptional activity in these conditions. Interestingly, treatment of 
E2F-RE-TK Luc, HEK-293

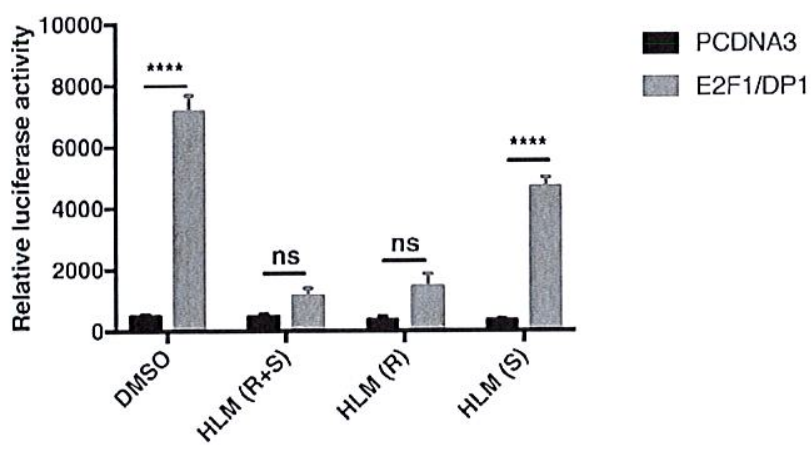

Fig. 4. HEK293 cells were treated for $48 \mathrm{~h}$ with DMSO (as a control), $10 \mu \mathrm{M}$ $(R+S)$-HLM006474, $10 \mu \mathrm{M}(R)$-HLM006474 or $10 \mu \mathrm{M}(S)$-HLM006474 and were transiently co-transfected with the E2F-RE-Tk promoter luciferase construct in the absence (pCDNA3) or presence of E2F1/DP1 heterodimer (E2F1/ DP1). Results were normalized to $\beta$-galactosidase activity. Data are shown as mean \pm SEM. ${ }^{\cdots *} p<0.001 ;$ ns $=$ not significant.

HEK293 cells with $10 \mu \mathrm{M}(S)$-HLM006474 maintained significant E2F1 transcriptional activity, supporting that this enantiomer has lower inhibitory properties on E2F1 DNA binding activity when compared to the $(R)$ enantiomer. These data suggest that the inhibitory effect of HLM006474 is mainly exerted by the $(R)$ enantiomer.

In conclusion, we have disclosed an efficient green synthesis of the E2F-DNA binding pan-inhibitor HLM006474 1. The key step in the synthesis is the three-component Betti reaction in solvent-free conditions allowing the yield, in thermal reaction conditions $(66 \%)$, to be multiplied by four and the reaction time $(24 \mathrm{~h})$ divided by ten compared to the precedent literature $\left(12 \%, 14\right.$ days). ${ }^{1}$ Using microwave reaction conditions, reaction time is even more decreased and $60-70 \%$ yields can also be obtained in few hours depending on the temperature and stoichiometry of the reactants.
The two enantiomers were separated using preparative chiral HPLC. This concise synthesis and preparative enantiomers separation offer opportunities to study the biological activities of the separated two enantiomers and observe an enhanced biological activity (inhibition activity) of the $(R)$-enantiomer that may lead to interesting clinical application in cancer therapy.

\section{Acknowledgments}

We gratefully thank the French 'Ministère de l'Éducation Nationale, de l'Enseignement Supérieur et de la Recherche' for financial support. Mrs Julie Vaurs and Mrs Romane Bourguet are acknowledged for technical assistance in chemistry. This work was supported by grants from «European Genomic Institute for Diabetes» (E.G.I.D, ANR-10LABX-46 to J-S. A.), Agence Nationale pour la Recherche, France (BETAPLASTICITY, ANR-17-CE14-0034 to J-S.A.); INSERM, CNRS, Lille University, France (to C.B. and J-S.A.).

\section{Appendix A. Supplementary data}

Supplementary data to this article can be found online at https:// doi.org/10.1016/j.bmcl.2018.12.037.

\section{References}

1. Ma Y, Kurtyka CA, Boyapalle S, et al. Cancer Res. 2008;68:6292-6299.

2. Kurtyka CA, Chen L, Cress WD. PLoS ONE. 2014;9 e96357.

3. Betti M. Gazz Chim Ital. 1900;30 II:301-309.

4. Cardellicchio C, Capozzi MAM, Naso F. TetrahedronAsymmet. 2010;21:507-517.

5. Betti M. Org. Synth. 1929;9:60.

6. Ghandi M, Olyaei A, Raoufmoghaddam S. J. Heterocycl. Chem. 2009;46:914-918,

7. Ghandi M, Olyaei A, Raoufmoghaddam S. Synth. Commun. 2008;38:4125-4138.

8. Kidwai M, Chauhan R. Asian. J. Org Chem. 2013;2:395-398.

9. Olyaei A, Raoufmoghaddam S, Sadeghpour M, Ebadzadeh B. Chin. J. Chem. 2010;28:825-832.

10. Jha A, Paul NK, Trikha S, Cameron TS. Can. J. Chem. 2006;84:843-853.

11. Szatmári I, Fülöp F. Synthesis. 2009;2009:775-778.

12. Sharifi A, Mirzaei M, Naimi-Jamal MR. Monatsh. Für. Chem. Chem. Mon. 2001;132:875-880. 